\title{
Challenges in Decoding Consumer Behavior with Data Science
}

\author{
Valentina Chkoniya \\ GOVCOPP, ISCA-UA, University of Aveiro, Portugal
}

\section{Abstract}

Decoding the ever-evolving consumer behavior is one of the biggest challenges faced by marketers around the world. The future of consumer behavior research is put into question by the advances in data science. Today, when consumers are all the time exposed to new technologies, trends such as facial recognition, artificial intelligence, and voice technology did not advance as rapidly as predicted, marketing intelligence gained a significant share of the spotlight. This paper gives an overview of possible ways to anticipate consumer data intelligence development from the perspectives of a robust data set and deep artificial intelligence expertise for better understanding, modeling, and predicting consumer behavior. Showing that marketing cannot happen in isolation in the era of digital overexposure, it requires a deeper understanding of consumer behavior. Data scientists, analysts, and marketers around the world have to work together to increase consumer loyalty, grow revenue, and improve the predictiveness of their models and effectiveness of their marketing spend. Efficiently integrating consumer behavior data into marketing strategies can help companies improve their approach towards attracting and winning the diverse and dynamic consumer segments and retaining them. This synthesis of current research will be helpful to both researchers and practitioners that work on the use of data science to understand and predict consumer behavior, as well as those making long-range planning marketing decisions.

Keywords: Data Science, Consumer Behaviour, Marketing Intelligence, Marketing Strategy, Consumer Data Intelligence

\section{Introduction}

Consumption continues to change with technological advancements and shifts in consumers' values and goals (Malter et al., 2020). The consumer is ultimately the key determinant of the success of an organization. The need for an in-depth and objective understanding of the consumers, therefore, in terms of what runs in their minds and hearts for the way they behave and act when they go about making complex purchase decisions cannot be over-emphasized (Moses \& Clark., 2020; Sankaran, 2019). Increasing global digitalization brings huge and evergrowing amounts of data (Skiera, 2016). Decoding the ever-evolving consumer behavior is one of the biggest challenges faced by marketers around the world. The adoption of contemporary methods in consumer data analytics is slow and many businesses fail to understand their consumers as well as they want. The future of consumer behavior research is put into question by the advances in data science. This paper gives an overview of possible ways to anticipate consumer data intelligence development from the perspectives of a robust data set and deep 
artificial intelligence expertise for better understanding, modeling, and predicting consumer behavior.

\section{Background}

In this section, an overview of Consumer Behavior Research and Data Science is given and definitions used for the analysis in this review are introduced.

\section{Consumer Behavior Research (CBR)}

In recent years, technological changes have significantly influenced the nature of consumption as the customer journey has transitioned to include more interaction on digital platforms that complements interaction in physical stores. Besides, this shift allows us to collect more data at different stages of the customer journey, which further allows us to analyze behavior in ways that were not previously available (Malter et al., 2020; Tong et al., 2020). Not only have technological advancements changed the nature of consumption but they have also significantly influenced the methods used in consumer research by adding both new sources of data and improved analytical tools (Ding et al., 2020; Ohme et al., 2020). The adoption of contemporary methods in consumer data analytics is slow and many businesses fail to understand their consumers as well as they want. The future of CBR is put into question by the advances in data science.

\section{Data science}

Data science (DS) combines multiple fields including statistics, scientific methods, and data analysis to extract value from data, being is an umbrella term used for multiple industries, such as data analytics, big data, marketing intelligence, data mining, machine learning and artificial intelligence, and predictive analytics, and is being increasingly adopted to analyze and predict consumer behavior (Cognetik, 2020; Sankaran, 2019).

Where:

Big Data. Big data is a collection of unstructured data that has very large volume, comes from variety of sources like web, business organizations etc. in different formats and comes to us with a great velocity which makes processing complex and tedious using traditional database management tools. The major demanding issues in big data processing include storage, search, distribution, transfer, analysis and visualization (Khade, 2016). In consumer behavior marketing, big data is used to analyze data points of a customer's journey from exploration to sale, powering marketers with tools and knowledge to make more informed decisions (Margalit, 2020; Saheb \& Saheb, 2020).

Data Mining. Data mining and analytics have played an important role in knowledge discovery and decision making/supports in the process industry over the past several decades (Ge et al., 2017). Data mining is defined as a process used to extract usable data from a larger set of any raw data. It implies analyzing data patterns in large batches of data using one or more software.

Predictive Analytics (PA). The most widely used data set in consumer behavior, and the one we'll be referring mostly to in this article, is PA. Predictive behavior modeling can reveal many insights to support marketing strategy. 
Machine Learning (ML). ML is used in DS to make predictions and also to discover patterns in the data, in situations where necessary the machine to learn from the big amounts of data, and then apply that knowledge to new pieces of data that streams into the system (Liu et al., 2018; Zolghadri \& Couffin, 2018).

Artificial Intelligence (AI). Some researchers propose that AI is the field of study that describes the capability of ML just like humans and the ability and refers to programs, algorithms, systems and machines that demonstrate intelligence (Khanna et al., 2020; Shankar, 2018). This paper follows another way to describe AI, that depends not on its underlying technology but rather its marketing and business applications, such as automating business processes, gaining insights from data, or engaging consumers and employees (Davenport et al., 2020).

Marketing Intelligence. The term marketing intelligence refers to developing insights obtained from data for use in marketing decision-making (Eggert \& Alberts, 2020). Data mining techniques can help to accomplish such a goal by extracting or detecting patterns or forecasting consumer behavior from large databases. Marketing intelligence has long been an implicit office standard, irrespective of specific big data solutions, systems or projects (Hu et al., 2019). It is already an implicit standard, because the term intelligence is often not even mentioned in science and practice, but impacts marketing practice as social engineering (Fan et al., 2015; Lies, 2019).

\section{Methodology}

To better understand challenges in decoding consumer behavior with DS, this paper presents a systematic literature review around the concepts, tools and techniques behind the increasing field of DS applied to CBR.

One way to achieve greater rigor and better levels of reliability in a literature review is to adopt a systematic approach, which allows the researcher to make a rigorous and reliable assessment of the research carried out within a specific topic (Brereton et al., 2007; Levy \& Ellis, 2006). The result must be the "state of the art" and demonstrate that the research in question contributes something new to the existing body of knowledge, the methodological approach is mainly supported in three phases: input; processing, and output (Sampaio, 2007). The input phase begins with the definition and presentation of the main goal of this research: "Determine the most recent applications of DS techniques in CBR context".

After that, continues with the process of data source identification requiring the definition of rigorous string that suits the different bibliographic databases selected. Scientific articles (ar) or conference proceedings (cp) related to CBR and DS from six main academic databases were searched. These academic databases include Springer Link, Web of Science, Scopus, IEEE Explore, Google Scholar, and Science Direct. Concerning the goal of identify the publications related to research works around the application of DS in CBR, in the first, it is used the string: TITLE-ABS-KEY ("DS") AND TITLE-ABS-KEY ("CBR") AND (LIMIT-TO (DOCTYPE, "cp") OR LIMIT-TO (DOCTYPE, "ar")). So, applying exclusion and inclusion criteria cited, the total document results are 1029. In this case, as all results are about recent articles, published between 2016 and 2020, in the English language.

All the publications titles and abstracts were read manually for relevance checking. This process resulted in 968 publications being excluded. Lastly, 61 eligible publications were 
selected and added 3 more from the snowballing process. The analyzed publications were investigated based on the relevance to the research domain and availability.

\section{Findings and Discussion}

A business may experience thousands of digital interactions with a single user across display, search, social, and on the site or app (He et al., 2018). These interactions take place on multiple devices, such as mobile, desktop, tablet, or wearable devices. Companies can use diverse consumer-related data (Batistič \& der Laken, 2019). However, with the rise of AI and ML algorithms, analyzing data points from multiple data sources to create a holistic view of users is now realistic and attainable (Bąska et al., 2019; Sá et al., 2018).

Impact of DS.

The impact of DS has been felt across a range of activities, by providing solutions for many industries that have been struggling for a long time. The most active data generators and consumers are the public sector, healthcare, manufacturing, and retail (Novikov, 2020).

Specifically, the big data and business analytics market was valued at USD 138.9 billion in 2020 and is forecasted to grow up to USD 229.4 billion by 2025, at a Compound Annual Growth Rate of $10.6 \%$ during the forecast period (Market Reports World, 2020).

The paths to transform digital information into value and to allow companies to become datadriven can be schematized into four major components, presented in Table 1 (Mikalef et al., 2018; Piccialli et al., 2020).

Table 1. Four major components.

\begin{tabular}{|c|c|c|}
\hline $\mathrm{N}$ & Component & Scope \\
\hline 1 & Descriptive Analytics & $\begin{array}{c}\text { concern most of the companies that use analytics tools aimed at } \\
\text { describing the current/past situation of business processes and/or } \\
\text { functional areas }\end{array}$ \\
\hline 2 & PA & $\begin{array}{c}\text { made up of advanced tools for data analysis and predictive models, } \\
\text { going further than analyzing the historical data, helps to make the } \\
\text { most educated guesses on what will happen in the future }\end{array}$ \\
\hline 3 & Prescriptive Analytics & $\begin{array}{r}\text { made up of advanced tools that allow decision-makers to have } \\
\text { operational and strategic solutions based on analyses. }\end{array}$ \\
\hline 4 & Automated Analytics & $\begin{array}{r}\text { tools that allow you to implement the actions that are the result of } \\
\text { analysis activities with forms of automation. }\end{array}$ \\
\hline
\end{tabular}

Recent strides in computing capabilities, increases in data transparency and open data sources, growth in the Internet of Things, and smartphone device usage are some of the drivers helping bridge the worlds of data, people, and things (Gupta et al., 2018). For many industries, DS has emerged as a leverage to predict trends and make informed decisions (Tkaczynski et al., 2018).

\section{The Connection Between DS and CBR}

Understanding how consumers think, feel, and respond to a company's offerings has always been a tricky business (Hsu, 2017). Marketing research relies on individual-level estimates to understand the rich heterogeneity of consumers, firms, and products (Dew et al., 2020). 
Accessibility to large datasets enables the application of complex DS algorithms and tools to process huge amounts of bytes of unstructured information, allowing relevant feature extraction and recognizing high-level abstractions with increasing generalizability. In this sense, DS tools, such as ML, have the potential to support several fields of research, including CBR, by the automation or resolution of complex tasks in time series prediction, classification, regression, diagnostics, monitoring, and so on (Exenberger \& Bucko, 2020; Górriz et al., 2020).

Data is the new currency for the future and there are four main consumer data types (Table 2) to find out how companies in different industries can use them (Dew et al., 2020; Kolsarici et al., 2020; McKenny et al., 2018; Moulik, 2020; Raza et a., 2020; Skiera, 2016; Tong et al., 2020; Torrens, 2018; Wang et al., 2018).

Table 2. Four main consumer data types.

\begin{tabular}{|c|c|c|c|}
\hline $\mathrm{N}$ & Data Type & Scope & Application \\
\hline 1 & $\begin{array}{c}\text { Transactional } \\
\text { data }\end{array}$ & $\begin{array}{l}\text { Transactional data relates } \\
\text { to the transactions of the } \\
\text { organization and includes } \\
\text { data that is captured }\end{array}$ & $\begin{array}{c}\text { In retail, purchase deepens a company's } \\
\text { understanding of its customers' } \\
\text { journeys }\end{array}$ \\
\hline 2 & $\begin{array}{l}\text { Data about } \\
\text { service/product } \\
\text { use }\end{array}$ & $\begin{array}{l}\text { Service/product usage data } \\
\text { tells you about the end- } \\
\text { user, what they are doing } \\
\text { while interacting with a } \\
\text { product, when they use it, } \\
\text { and for how long }\end{array}$ & $\begin{array}{l}\text { Manufacturers can examine the data } \\
\text { about product use to create a better } \\
\text { customer experience, identify trends, } \\
\text { gauge feature popularity, create product } \\
\text { training tools, innovate etc. }\end{array}$ \\
\hline 3 & $\begin{array}{c}\text { Web behavior } \\
\text { data }\end{array}$ & $\begin{array}{l}\text { A company can analyze } \\
\text { every move that their } \\
\text { website visitors make: } \\
\text { where they come from, } \\
\text { which pages they open, } \\
\text { how deep visitors' } \\
\text { engagement is, etc. }\end{array}$ & $\begin{array}{l}\text { Online stores apply this logic to track } \\
\text { consumer behavior, identify consumer } \\
\text { preferences, and make product } \\
\text { recommendations with the help of PA }\end{array}$ \\
\hline 4 & $\begin{array}{l}\text { Data from } \\
\text { consumer- } \\
\text { created texts }\end{array}$ & $\begin{array}{l}\text { Data generated by } \\
\text { consumers in the form of } \\
\text { text messages, reviews, } \\
\text { tweets, emails, posts, and. } \\
\text { blogs }\end{array}$ & $\begin{array}{l}\text { Brands can study this content to better } \\
\text { understand what their consumers think } \\
\text { about their product or service by } \\
\text { identifying trends, recognizing a positive } \\
\text { or negative emotional tone of each piece } \\
\text { of text, revealing complaints and } \\
\text { problems to solve }\end{array}$ \\
\hline
\end{tabular}

The ability of DS to visualize consumer behavior has enabled to predict consumer likes and dislikes and has taken the capabilities beyond mere data collection and analysis. By incorporating the right tools and processes, businesses can now efficiently utilize the insights to influence the decisions of consumers through robust communication (Finoti et al., 2019).

\section{Taking Consumer Behavior to the Next Level with DS}

Behavioral research in information systems employing quantitative methods has traditionally relied on mainly survey-based approaches to gather subjective user data. With new advances in technology such as mobile computing, wearable devices, and social media, along with computational capabilities, organizations are in a position to leverage objective data in 
addressing IT issues typically addressed in behavioral research (Ducange et al., 2018; Motiwalla et al., 2019). DS takes data analysis to the next level, allowing businesses to predict what users might do (Khade, 2016).

Consumer analytics play an essential role in organizations since businesses have access to vast consumer interaction data from multiple channels, including mobile, social media, stores, and e-commerce sites (Chung \& Park, 2018). Intended to provide the answers to diverse consumer-related questions, consumer analytics can embrace different types of business analytics. Relying on DS and ML, these two types can provide forecasts and recommend actions that a business can take (Auder et al., 2018).

Key concepts (Table 3) of Consumer analytics (Ahmad et al., 2019; Dew et al., 2020; Immonen et al., 2018; Khade, 2016; Khatri \& Samuel, 2019; Kulczycki \& Franus, 2020) :

Table 3. Key concepts of Consumer analytics

\begin{tabular}{|c|c|c|c|}
\hline $\mathrm{N}$ & Concept & Scope & Application \\
\hline 1 & $\begin{array}{c}\text { Venn } \\
\text { Diagram }\end{array}$ & $\begin{array}{l}\text { Discover Hidden Relationships. } \\
\text { Combine multiple segments to discover } \\
\text { connections, relationships, or differences }\end{array}$ & $\begin{array}{l}\text { Explore consumers that have } \\
\text { bought different categories of } \\
\text { products and easily identify } \\
\text { cross-selling opportunities }\end{array}$ \\
\hline 2 & $\begin{array}{c}\text { Data } \\
\text { Profiling }\end{array}$ & $\begin{array}{c}\text { Identify Consumer Attributes } \\
\text { Select records from the data tree and } \\
\text { generate consumer profiles that indicate } \\
\text { common features and behaviors }\end{array}$ & $\begin{array}{l}\text { Use consumer profiles to inform } \\
\text { effective sales and marketing } \\
\text { strategies }\end{array}$ \\
\hline 3 & $\begin{array}{c}\text { Time Series } \\
\text { Analysis }\end{array}$ & Forecasting & $\begin{array}{l}\text { Forecasting enables us to adapt } \\
\text { to changes, trends, and seasonal } \\
\text { patterns. }\end{array}$ \\
\hline 4 & Mapping & $\begin{array}{c}\text { Identify Geographical Zones } \\
\text { Mapping uses color-coding to indicate } \\
\text { consumer behavior as it changes across } \\
\text { geographic regions }\end{array}$ & $\begin{array}{l}\text { A map divided into polygons that } \\
\text { represent geographic regions } \\
\text { shows where potential churners } \\
\text { are or where specific products } \\
\text { better sell } \\
\end{array}$ \\
\hline 5 & $\begin{array}{l}\text { Association } \\
\text { Rules }\end{array}$ & $\begin{array}{c}\text { Cause/ Effect } \\
\text { Basket Analysis }\end{array}$ & $\begin{array}{l}\text { This technique detects } \\
\text { relationship or affinity patterns } \\
\text { across data and generates a set of } \\
\text { rules that are most useful to } \\
\text { business insights }\end{array}$ \\
\hline 6 & $\begin{array}{l}\text { Decision } \\
\text { Tree }\end{array}$ & $\begin{array}{l}\text { Classify and Predict Behavior } \\
\text { Decision trees are one of the most } \\
\text { popular methods for classification in } \\
\text { various data mining applications and } \\
\text { assist the process of decision making }\end{array}$ & $\begin{array}{l}\text { Classification helps you do things } \\
\text { like select the right products to } \\
\text { recommend to particular } \\
\text { consumers and predict potential } \\
\text { churn }\end{array}$ \\
\hline
\end{tabular}

Consumer Behavior Analysis makes it possible to provide business decision-making information that contributes to the achievement of business goals, with the primary benefit being profit (Exenberger \& Bucko, 2020).

Table 4 shows four strategic focus areas where PA can help increase profit (Alvi et al., 2019; Canakoglu et al., 2018; Chagas et al., 2020; Chkoniya \& Mateus, 2019; Davenport et al., 2020; Ernst \& Dolnicar, 2018; Fainshtein \& Serova, 2020; Gallino \& Rooderkerk, 2020; Khanna et al., 
2020; Kuehn, 2020; Le \& Liaw, 2017; Luu \& Lim, 2018; Schmidt et al., 2020; Swain \& Cao, 2019; Tarnowska \& Ras, 2019; Voicu, 2020).

Table 4. Four strategic focus areas

\begin{tabular}{|c|c|c|c|}
\hline $\mathrm{N}$ & Focus Area & Scope & Application \\
\hline 1 & $\begin{array}{c}\text { Personalized } \\
\text { Marketing }\end{array}$ & $\begin{array}{c}\text { By segmenting the market into } \\
\text { specific subgroups based on } \\
\text { similarities in behaviors, } \\
\text { geographic location, or other } \\
\text { demographics, marketers can } \\
\text { better target groups }\end{array}$ & $\begin{array}{c}\text { Generate customized } \\
\text { recommendations based on a user's } \\
\text { watch history, highlighting products } \\
\text { consumer may be interested in }\end{array}$ \\
\hline 2 & $\begin{array}{c}\text { Demand } \\
\text { Pricing }\end{array}$ & $\begin{array}{c}\text { By evaluating the purchasing } \\
\text { trends of consumers in each data } \\
\text { set, marketers can better see } \\
\text { what effect pricing decisions have } \\
\text { on demand }\end{array}$ & $\begin{array}{c}\text { More competitive pricing model over } \\
\text { to surge pricing after noticeable } \\
\text { changes in demand at various points } \\
\text { throughout the year }\end{array}$ \\
\hline 3 & Resource & $\begin{array}{c}\text { With PA in place, a company can } \\
\text { better forecast and segment } \\
\text { where resources will need to be } \\
\text { allocated to the most }\end{array}$ & $\begin{array}{c}\text { Having properly allocated resources } \\
\text { in place is vital to achieving your } \\
\text { organization's objectives. }\end{array}$ \\
\hline 4 & Forecasting & $\begin{array}{c}\text { Arguably one of the most } \\
\text { significant benefits of using data } \\
\text { in consumer behavior analytics is } \\
\text { forecasting }\end{array}$ & $\begin{array}{c}\text { Creates intelligent and evidence- } \\
\text { based estimates of sales goals based } \\
\text { upon current and past sales } \\
\text { performance reports. }\end{array}$ \\
\hline
\end{tabular}

\section{Conclusion}

In the future, AI is likely to substantially change both marketing strategies and consumer behaviors (Davenpor et al., 2020). The efficient implementation of DS will enable organizations to enhance the overall consumer experience by developing robust data analytics models (Fernández-Manzano \& González-Vasco, 2018). In particular, marketers must incorporate analytics into their daily decisions around lead generation campaigns, advertising, events and the myriad other ways marketing investments are allocated to affect consumer satisfaction, brand awareness, trust, loyalty, consumer perceived value and consumer retention (Mosavi et al., 2018; Motiwalla et al., 2019).

This paper intended to give an overview of possible ways to anticipate consumer data intelligence development from the perspectives of a robust data set and deep AI expertise for better understanding, modeling, and predicting consumer behavior.

\section{References}

[1] Ahmad, S. R., Bakar, A. A., \& Yaakub, M. R. (2019). A review of feature selection techniques in sentiment analysis. Intelligent Data Analysis, 23(1), 159-189. https://doi.org/10.3233/IDA173763

[2] Alvi, A. K., Butt, U. U., \& Zulqarnain, M. (2019). Mediating role of brand equity between the relationship of brand experience and brand preference. Gomal University Journal of Research, 35(2), 32-41.

[3] Auder, B., Cugliari, J., Goude, Y., \& Poggi, J.-M. (2018). Scalable Clustering of Individual Electrical Curves for Profiling and Bottom-Up Forecasting. Energies (19961073), 11(7), 1893. https://doi.org/10.3390/en11071893 
[4] Bąska, M., Pondel, M., \& Dudycz, H. (2019). Identification of advanced data analysis in marketing: A systematic literature review. Journal of Economics \& Management, 35(1), 18-39. https://doi.org/10.22367/jem.2019.35.02

[5] Batistič, S., \& der Laken, P. (2019). History, Evolution and Future of Big Data and Analytics: A Bibliometric Analysis of Its Relationship to Performance in Organizations. British Journal of Management, 30(2), 229-251. https://doi.org/10.1111/1467-8551.12340

[6] Brereton, P., Kitchenham, B. A., Budgen, D., Turner, M., \& Khalil, M. (2007). Lessons from applying the systematic literature review process within the software engineering domain. Journal of Systems and Software, 80(4), 571-583. https://doi.org/10.1016/j.jss.2006.07.009

[7] Canakoglu, E., Erzurumlu, S. S., \& Erzurumlu, Y. O. (2018). How Data-Driven Entrepreneur Analyzes Imperfect Information for Business Opportunity Evaluation. IEEE Transactions on Engineering Management, 65(4), 604-617. https://doi.org/10.1109/TEM.2018.2826983

[8] Chagas, B. N. R., Viana, J., Reinhold, O., Lobato, F. M. F., Jacob Jr., A. F. L., \& Alt, R. (2020). A literature review of the current applications of machine learning and their practical implications. Web Intelligence (2405-6456), 18(1), 69-83. https://doi.org/10.3233/WEB-200429

[9] Chkoniya, V. \& Mateus, A. (2019). Digital Category Management: How Technology Can Enable the Supplier-Retailer Relationship. https://doi.org/10.4018/978-1-5225-5763-0.ch008

[10] Chung, C. J., \& Park, H. W. (2018). Beyond data, innovation, social network, and convergence. Quality \& Quantity, 52(2), 515-518. https://doi.org/10.1007/s11135-017-0669-2

[11] Cognetik, (2020). Leveraging Data Science to Understand User Behavior. Digital Marketing.

[12] Davenport, T., Guha, A., Grewal, D., \& Bressgott, T. (2020). How artificial intelligence will change the future of marketing. Journal of the Academy of Marketing Science, 48(1), 24-42.

[13] Dew, R., Ansari, A., \& Li, Y. (2020). Modeling Dynamic Heterogeneity Using Gaussian Processes. Journal of Marketing Research (JMR), 57(1), 55-77. https://doi.org/10.1177/0022243719874047

[14] Ding, Y., DeSarbo, W. S., Hanssens, D. M., Jedidi, K., Lynch, J. G., \& Lehmann, D. R. (2020). The past, present, and future of measurement and methods in marketing analysis. Marketing Letters, 31(2), 175-186. https://doi.org/10.1007/s11002-020-09527-7

[15] Ducange, P., Pecori, R., \& Mezzina, P. (2018). A glimpse on big data analytics in the framework of marketing strategies. Soft Computing - A Fusion of Foundations, Methodologies \& Applications, 22(1), 325-342. https://doi.org/10.1007/s00500-017-2536-4

[16] Eggert, M., \& Alberts, J. (2020). Frontiers of business intelligence and analytics 3.0: a taxonomybased literature review and research agenda. Business Research, 13(2), 685-739. https://doi.org/10.1007/s40685-020-00108-y

[17] Ernst, D., \& Dolnicar, S. (2018). How to Avoid Random Market Segmentation Solutions. Journal of Travel Research, 57(1), 69-82. https://doi.org/10.1177/0047287516684978

[18] Exenberger, E., \& Bucko, J. (2020). Analysis of Online Consumer Behavior - Design of CRISP-DM Process Model. Agris On-Line Papers in Economics \& Informatics, (3), 13-22. https://doi.org/10.7160/aol.2020.120302

[19] Fainshtein, E., \& Serova, E. (2020). Value Proposition of Network Companies Providing Restaurant Services in Russia: Analysis and Evaluation (pp. 137-158). IGI Global. https://doi.org/http://doi:10.4018/978-1-7998-3115-0.ch008

[20] Fan, S., Lau, R. Y. K., \& Zhao, J. L. (2015). Demystifying Big Data Analytics for Business Intelligence Through the Lens of Marketing Mix. Big Data Research, 2(1), 28-32. https://doi.org/10.1016/j.bdr.2015.02.006

[21] Fernández-Manzano, E.-P., \& González-Vasco, M.-I. (2018). Analytic surveillance: big data business models in the time of privacy awarenesS. El Profesional de La Información, 27(2), 402409. https://doi.org/10.3145/epi.2018.mar.19

[22] Finoti, L. L., Toaldo, A. M. M., Schwarzbach, L. C., \& Marchetti, R. Z. (2019). Marketing Strategy Process: analyzing the sequential relationships among its strategic activities. Revista Brasileira de Gestão de Negócios, 21(5), 767-787. https://doi.org/10.7819/rbgn.v21i5.4031

[23] Gallino, S., \& Rooderkerk, R. (2020). New Product Development in an Omnichannel World. California Management Review, 63(1), 81-98. https://doi.org/10.1177/0008125620951969

[24] Ge, Z., Song, Z., Ding, S. X., \& Huang, B. (2017). Data Mining and Analytics in the Process Industry: The Role of Machine Learning. IEEE Access, 5, 20590-20616. https://doi.org/10.1109/ACCESS.2017.2756872

[25] Górriz, J. M., Ramírez, J., Ortíz, A., Martínez-Murcia, F. J., Segovia, F., Suckling, J., ... Ferrández, J. M. (2020). Artificial intelligence within the interplay between natural and artificial 
computation: Advances in data science, trends and applications. Neurocomputing, 410, 237270. https://doi.org/https://doi.org/10.1016/j.neucom.2020.05.078

[26] Gupta, A., Deokar, A., Iyer, L., Sharda, R., \& Schrader, D. (2018). Big Data \& Analytics for Societal Impact: Recent Research and Trends. Information Systems Frontiers, 20(2), 185-194. https://doi.org/10.1007/s10796-018-9846-7

[27] He, W., Tian, X., Hung, A., Akula, V., \& Zhang, W. (2018). Measuring and comparing service quality metrics through social media analytics: a case study. Information Systems \& E-Business Management, 16(3), 579-600. https://doi.org/10.1007/s10257-017-0360-0

[28] Hsu, M. (2017). Neuromarketing: inside the mind of the consumer. California Management Review, 59(4), 5-22.

[29] Hu, Y., Xu, A., Hong, Y., Gal, D., Sinha, V., \& Akkiraju, R. (2019). Generating Business Intelligence Through Social Media Analytics: Measuring Brand Personality with Consumer-, Employee-, and Firm-Generated Content. Journal of Management Information Systems, 36(3), 893-930. https://doi.org/10.1080/07421222.2019.1628908

[30] Immonen, A., Ovaska, E., \& Paaso, T. (2018). Towards certified open data in digital service ecosystems. Software Quality Journal, 26(4), 1257-1297. https://doi.org/10.1007/s11219-0179378-2

[31] Khade, A. A. (2016). Performing Customer Behavior Analysis using Big Data Analytics. Procedia Computer Science, 79, 986-992. https://doi.org/https://doi.org/10.1016/j.procs.2016.03.125

[32] Khanna, V., Ahuja, R., \& Popli, H. (2020). Role of artificial intelligence in pharmaceutical marketing: a comprehensive review. Journal of Advanced Scientific Research, 11(3), 54-61.

[33] Khatri, V., \& Samuel, B. M. (2019). Analytics for Managerial Work. Communications of the ACM. https://doi.org/10.1145/3274277

[34] Kolsarici, C., Vakratsas, D., \& Naik, P. A. (2020). The Anatomy of the Advertising Budget Decision: How Analytics and Heuristics Drive Sales Performance. Journal of Marketing Research (JMR), 57(3), 468-488. https://doi.org/10.1177/0022243720907578

[35] Kuehn, K. S. (2020). Personalization 3.0: How Personality Can Predict Consumer Behavior (pp. 22-50). IGI Global. http://doi:10.4018/978-1-7998-3115-0.ch002

[36] Kulczycki, P., \& Franus, K. (2020). Methodically Unified Procedures for a Conditional Approach to Outlier Detection, Clustering, and Classification. Information Sciences. https://doi.org/10.1016/j.ins.2020.08.122

[37] Le, T. M., \& Liaw, S.-Y. (2017). Effects of Pros and Cons of Applying Big Data Analytics to Consumers' Responses in an E-Commerce Context. Sustainability, 9(5), 798. https://doi.org/10.3390/su9050798

[38] Levy, Y., \& Ellis, T. (2006). A Systems Approach to Conduct an Effective Literature Review in Support of Information Systems Research. International Journal of an Emerging Transdiscipline, 9. https://doi.org/10.28945/479

[39] Lies, J. (2019). Marketing Intelligence and Big Data: Digital Marketing Techniques on their Way to Becoming Social Engineering Techniques in Marketing. International Journal of Interactive Multimedia and Artificial Intelligence, 5(5), 134-144. https://doi.org/10.9781/ijimai.2019.05.002

[40] Liu, Q., Feng, G., Wang, N., \& Tayi, G. K. (2018). A multi-objective model for discovering highquality knowledge based on data quality and prior knowledge. Information Systems Frontiers, 20(2), 401-416. https://doi.org/10.1007/s10796-016-9690-6

[41] Luu, M.-D., \& Lim, E.-P. (2018). Do your friends make you buy this brand? Data Mining \& Knowledge Discovery, 32(2), 287-319. https://doi.org/10.1007/s10618-017-0535-9

[42] Malter, M. S., Holbrook, M. B., Kahn, B. E., Parker, J. R., \& Lehmann, D. R. (2020). The past, present, and future of consumer research. Marketing Letters, 31(2/3), 137-149. https://doi.org/10.1007/s11002-020-09526-8

[43] Margalit, L. (2020). If You Want to Trigger an Emotional Purchase, Don't Make Your Customers Think: Understanding Customer Decision Making (pp. 176-192). IGI Global. http://doi:10.4018/978-1-7998-3115-0.ch010

[44] Market Reports World. (2020). Big Data Market by Component, Deployment Mode, Organization Size, Business Function (Operations, Finance, and Marketing and Sales), Industry Vertical (BFSI, Manufacturing, and Healthcare and Life Sciences), and Region - Global Forecast to 2025.

[45] McKenny, A. F., Aguinis, H., Short, J. C., \& Anglin, A. H. (2018). What Doesn't Get Measured Does Exist: Improving the Accuracy of Computer-Aided Text Analysis. Journal of Management, 44(7), 2909-2933. https://doi.org/10.1177/0149206316657594 
[46] Mikalef, P., Pappas, I. O., Krogstie, J., \& Giannakos, M. (2018). Big data analytics capabilities: a systematic literature review and research agenda. Information Systems \& E-Business Management, 16(3), 547-578. https://doi.org/10.1007/s10257-017-0362-y

[47] Mosavi, S. M., Sangari, M. S., \& Keramati, A. (2018). An integrative framework for customer switching behavior. Service Industries Journal, 38(15/16), 1067-1094. https://doi.org/10.1080/02642069.2018.1428955

[48] Moses, E., \& Clark., K. R. (2020). The Neuromarketing Revolution: Bringing Science and Technology to Marketing Insight (pp. 449-464). Hershey, PA, USA: IGI Global. http://doi:10.4018/978-1-7998-3115-0.ch024

[49] Motiwalla, L., Deokar, A. V, Sarnikar, S., \& Dimoka, A. (2019). Leveraging Data Analytics for Behavioral Research. Information Systems Frontiers, 21(4), 735-742. https://doi.org/10.1007/s10796-019-09928-8

[50] Moulik, S. (2020). Data as the New Currency-How Open Source Toolkits Have Made Labeled Data the Core Value in the AI Marketplace. Academic Radiology, 27(1), 140-142. https://doi.org/10.1016/j.acra.2019.09.016

[51] Novikov, S. V. (2020). Data Science and Big Data Technologies Role in the Digital Economy. TEM Journal, 9(2), 756-762. Retrieved from http://10.0.71.245/tem92-44

[52] Ohme, R., Matukin, M., \& Wicher, P. (2020). Merging Explicit Declarations with Implicit Response Time to Better Predict Behavior (pp. 427-448). IGI Global. http://doi:10.4018/978-17998-3115-0.ch023

[53] Piccialli, F., Bessis, N., \& Jung, J. J. (2020). Guest Editorial: Data Science Challenges in Industry 4.0. IEEE Transactions on Industrial Informatics, Industrial Informatics, IEEE Transactions on, IEEE Trans. Ind. Inf., 16(9), 5924-5928. https://doi.org/10.1109/TII.2020.2984061

[54] Raza, M., Abd Rani, S. H., \& Md Isa, N. (2020). Determinants of brand authenticity of high quality appareL INDUSTRY IN DEVELOPING COUNTRY: A MODERATING EFFECT OF ENTREPRENEURIAL. International Journal for Quality Research, 14(3), 913-930. https://doi.org/10.24874/IJQR14.03-17

[55] Sá, C. R. de, Duivesteijn, W., Azevedo, P., Jorge, A. M., Soares, C., \& Knobbe, A. (2018). Discovering a taste for the unusual: exceptional models for preference mining. Machine Learning, 107(11), 1775-1807. https://doi.org/10.1007/s10994-018-5743-z

[56] Saheb, T., \& Saheb, T. (2020). Understanding the development trends of big data technologies: an analysis of patents and the cited scholarly works. Journal of Big Data, 7(1), 1-26. https://doi.org/10.1186/s40537-020-00287-9

[57] Sampaio, R. (2007). Estudos de revisão sistemática: um guia para síntese criteriosa da evidência científica. Revista Brasileira De Fisioterapia, 11. https://doi.org/10.1590/S141335552007000100013

[58] Sankaran, V. (2019). Empowering Consumer Research with Data Science. 2019 Amity International Conference on Artificial Intelligence (AICAI), Artificial Intelligence (AICAI), 2019 Amity International Conference On. https://doi.org/10.1109/AICAI.2019.8701356

[59] Schmidt, P. J., Church, K. S., \& Riley, J. (2020). Clinging to Excel as a Security Blanket: Investigating Accountants' Resistance to Emerging Data Analytics Technology. Journal of Emerging Technologies in Accounting, 17(1), 33-39. https://doi.org/10.2308/jeta-52645

[60] Shankar, V. (2018). How Artificial Intelligence (AI) is Reshaping Retailing. Journal of Retailing, 94(4), vi-xi. https://doi.org/https://doi.org/10.1016/S0022-4359(18)30076-9

[61] Skiera, B. (2016). Data, Data and Even More Data: Harvesting Insights from the Data Jungle. GfK-Marketing Intelligence Review, 8(2) https://doi.org/10.1515/gfkmir-2016-0010

[62] Swain, A. K., \& Cao, R. Q. (2019). Using sentiment analysis to improve supply chain intelligence. Information Systems Frontiers, 21(2), 469.

[63] Tarnowska, K. A., \& Ras, Z. W. (2019). Sentiment analysis of customer data. Web Intelligence (2405-6456), 17(4), 343-363. https://doi.org/10.3233/WEB-190423

[64] Tkaczynski, A., Rundle-Thiele, S. R., \& Prebensen, N. K. (2018). To segment or not? That is the question. Journal of Vacation Marketing, 24(1), 16-28. https://doi.org/10.1177/1356766716679482

[65] Tong, S., Luo, X., \& Xu, B. (2020). Personalized mobile marketing strategies. Journal of the Academy of Marketing Science, 48(1), 64-78. Retrieved from http://10.0.3.239/s11747-01900693-3 
[66] Torrens, G. E. (2018). The order and priority of research and design method application within an assistive technology new product development process: a summative content analysis of 20 case studies. Disability \& Rehabilitation: Assistive Technology, 13(1), 66-77. https://doi.org/10.1080/17483107.2017.1280547

[67] Voicu, M.-C. (2020). Research on the Impact of Social Media on Consumer Trust. Global Economic Observer, 8(1), 120-132.

[68] Wang, W. M., Li, Z., Liu, L., Tian, Z. G., \& Tsui, E. (2018). Mining of affective responses and affective intentions of products from unstructured text. Journal of Engineering Design, 29(7), 404-429. https://doi.org/10.1080/09544828.2018.1448054

[69] Zolghadri, M., \& Couffin, F. (2018). One-off or batch upgrading of complex products and systems: concepts, data model and analysis framework. Research in Engineering Design, 29(2), 263-284. https://doi.org/10.1007/s00163-017-0268-1 